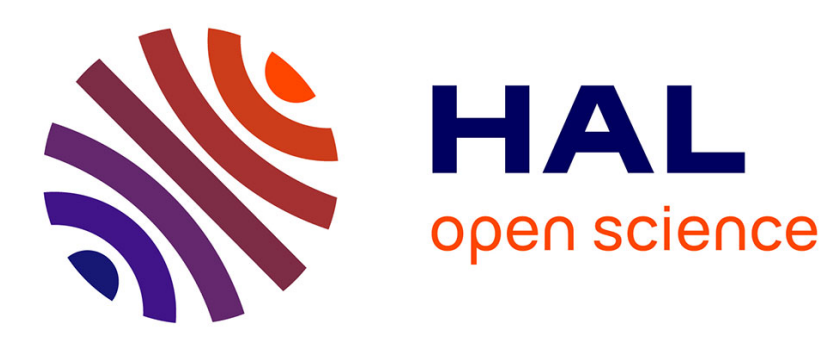

\title{
Acid-tolerant Collembola cannot colonize metal-polluted soils at neutral $\mathrm{pH}$
}

Sébastien Garnier, Jean-François Ponge

\section{To cite this version:}

Sébastien Garnier, Jean-François Ponge. Acid-tolerant Collembola cannot colonize metal-polluted soils at neutral pH. Applied Soil Ecology, 2004, 26 (3), pp.201-208. 10.1016/j.apsoil.2004.01.002 . hal-00497189

\section{HAL Id: hal-00497189 \\ https://hal.science/hal-00497189}

Submitted on 2 Jul 2010

HAL is a multi-disciplinary open access archive for the deposit and dissemination of scientific research documents, whether they are published or not. The documents may come from teaching and research institutions in France or abroad, or from public or private research centers.
L'archive ouverte pluridisciplinaire HAL, est destinée au dépôt et à la diffusion de documents scientifiques de niveau recherche, publiés ou non, émanant des établissements d'enseignement et de recherche français ou étrangers, des laboratoires publics ou privés. 
1 Type of contribution: Regular paper

2

3 Date of preparation: 2003-12-10

4

5 Number of text pages: 16

6

$7 \quad$ Number of tables: 1

8

9 Number of figures: 2

10

11 Title: ACID-TOLERANT COLLEMBOLA CANNOT COLONIZE METAL-POLLUTED 12 SOILS AT NEUTRAL PH

13

14 Authors: S. Garnier ${ }^{1}$, J.F. Ponge*1

15

16 * Corresponding author: fax +33 1 60465009, E-mail: jean-francois.ponge@wanadoo.fr 17

$18{ }^{1}$ Museum National d'Histoire Naturelle, CNRS UMR 5176, 4 avenue du Petit-Chateau, 1991800 Brunoy, France

20 


\title{
Acid-tolerant Collembola cannot colonize metal-polluted soils at neutral pH
}

\author{
Sébastien Garnier, Jean-François Ponge
}

Museum National d'Histoire Naturelle, CNRS UMR 5176, 4 avenue du Petit-Chateau, 91800 Brunoy, France

\section{Abstract}

A microcosm experiment was performed to test the hypothesis that Collembola living in an acid soil ( $\mathrm{pH} 4)$ were able to colonize a heavy metal-polluted soil of $\mathrm{pH} 7$. After 6-month incubation, the added fauna were not recovered, except for a few individuals, while the original fauna were still as abundant as at the beginning of the experiment. It was concluded that, despite similarities between the chemical environment of acid soils and that of metal-polluted soils, differences in biotic and abiotic factors prevent acid-tolerant populations to survive and reproduce in a polluted site.

Keywords: Heavy metals, Collembola, Acid-tolerance, Inoculation

\section{Introduction}

The use of acid-tolerant organisms for the bioremediation of polluted soils has been proposed, on the basis of affinities between the chemical environment of acid and polluted soils, in particular those polluted with heavy metals (Chauvat and Ponge, 2002; Gillet and Ponge, submitted). The lack of metal specificity in detoxication mechanisms of soil invertebrates (Vandenbulcke et al., 1998; Köhler, 2002), and the presence of free (ionic) forms of aluminum, iron, manganese and other metals at low 
$1 \mathrm{pH}$ (Tan, 1982), suggested that tolerance to acidity could allow tolerance to a broad

2 range of heavy metals, too. However, neutral $\mathrm{pH}$, excess of calcium and dramatic

3 changes in food resources and habitat could affect survival and reproductive rate upon

4 inoculation to metal-polluted sites (Kreutzer, 1995; Gillet and Ponge, 2002, 2003). The

5 objective of this study was to initiate a self-reinforcing process by adding more, better

6 adapted fauna, in order to i) stimulate humification (Bernier, 1998; Ponge, 1999;

7 Davidson et al., 2002), ii) increase the number of micro-sites able to fix heavy metals

8 (Senesi et al., 1987; Dupuy and Douay, 2001), thus preventing metals from circulating

9 through the ecosystem.

10

Several experiments were performed to check whether acid-tolerant Collembola were able to colonize heavy-metal polluted soils. Short-term microcosm experiments using compartmented boxes showed that some species dispersed from an acid source (a dysmoder humus of $\mathrm{pH} 4$ ) to a neutral soil heavily polluted with metals such as lead, zinc, or cadmium (Chauvat and Ponge, 2002; Gillet and Ponge, submitted). However, these dispersal experiments were of a too short duration for allowing reproduction and survival success to be assessed. A field site polluted with zinc, cadmium and lead was inoculated with microarthropods but resampling of the site after 7 and 14 months failed to reveal any significant dispersal from the inoculum, which kept its original population even after 14 months (Gillet, unpublished data). We suspected that the animals did not disperse to a great extent because they were not forced to leave their original habitat under environmental pressure (Tranvik and Eijsackers, 1989). As a consequence, it was decided to perfom laboratory experiments, into which a known amount of acidtolerant fauna could be introduced and monitored over six months, thus allowing the assessment of survival and reproduction of the introduced population. This time lapse was within a range between one generation time (1 to 2 months) and maximum longevity (1 to 2 years) for most Collembola (Siepel, 1994). 


\section{2. Materials and methods}

The acid soil used for inoculating acid-tolerant fauna was a dysmoder humus

4 (Brêthes et al., 1995) of $\mathrm{pH} \mathrm{H}_{2} \mathrm{O} 4.4$ and $\mathrm{pH} \mathrm{KCl} \mathrm{3.3,} \mathrm{originating} \mathrm{from} \mathrm{a} \mathrm{beech} \mathrm{forest} \mathrm{at}$ 5 Willerzie, Belgium (Ponge et al., 1997; Gillet and Ponge, submitted). The metal6 polluted soil was obtained from a field downwind a zinc smelter at Auby, France. It 7 corresponded to the most polluted plot P1, as described in Gillet and Ponge (2002, 8 2003). The top $10 \mathrm{~cm}$ of the soil, which was a mor humus (Ponge et al., 2000) of pH $9 \mathrm{H}_{2} \mathrm{O} 6.9$ and $\mathrm{pH} \mathrm{KCl} \mathrm{6.5,} \mathrm{contained} \mathrm{35,000} \mathrm{mg/kg} \mathrm{of} \mathrm{Zn} \mathrm{(Gillet} \mathrm{and} \mathrm{Ponge,} \mathrm{2003),} \mathrm{half} \mathrm{of}$ which was in a bioavailable form (Gillet and Ponge, submitted). The two soils were collected on the same day (2002.09.22). They included only ectorganic horizons, which were homogenized by hand in a large plastic sheet after discarding fresh litter and ground vegetation. After homogenization, samples were directly put in microcosms before transport to the laboratory.

Experimental microcosms were $11 \times 8 \times 4 \mathrm{~cm}(\mathrm{~L} \times \mathrm{I} \times \mathrm{h})$ polystyrene boxes with 17 lids, which were filled with soil, leaving enough overhead space for free movement of surface-active invertebrates. Lids were pierced at their centre with a $2 \mathrm{~cm}$ diameter hole, covered with nylon gauze, to allow gas exchange with the surrounding atmosphere. Ten replicates with the polluted soil $\left(300 \mathrm{~cm}^{3}\right)$ were kept closed without any further treatment. Ten other replicates were placed under Berlese funnels used for the extraction of microarthropods (Edwards and Fletcher, 1971) and were inoculated with fauna from $300 \mathrm{~cm}^{3}$ dysmoder humus. In parallel, microarthropods from $300 \mathrm{~cm} 3$ of both substrates were extracted using the same method. During the extraction, which took 10 days, uninoculated boxes were also incubated in the extractor. Once the

26 inoculation was completed, all microcosms (10 inoculated, 10 uninoculated) were 27 incubated in an air-forced chamber at constant temperature $\left(15^{\circ} \mathrm{C}\right)$, in darkness. 
1 Incubation lasted for 6 months, after which time microarthropods were extracted in the 2 same way.

The microcosms were kept at field moisture, their weight being kept constant by adding deionized water each fortnight.

Extracted animals were collected and preserved in 95\% ethyl alcohol. They were sorted under a dissecting microscope and mounted in chloral-lactophenol for examination in phase contrast microscopy. Several keys were used for the identification of Collembolan species. In particular the (still experimental) key by Hopkin (in prep.) was judged very handy. It was completed by more detailed monographs by Gisin (1960), Zimdars \& Dunger (1994), Jordana et al. (1997), Fjellberg (1998), Bretfeld (1999) and Potapov (2001).

A special attention was apid to the tullbergiid species Mesaphorura macrochaeta Rusek. The sex ratio of adult specimens was determined after pooling all animals from the same treatment (Dysmoder, Original Mor, Incubated Mor, Inoculatedincubated Mor). We have noted before that this parthenogenetic species shifted to sexual reproduction under environmental stress, including pollution by heavy metals (Niklasson et al., 2000; Gillet and Ponge, 2003). The gut contents of all specimens of M. macrochaeta were examined under phase contrast and classified into 6 categories (Empty guts, Holorganic humus, Hemorganic humus, Fungi, Bacteria, Exuviae), since it has been shown that the same species changed its food diet when submitted to a higher dose of heavy metals (Gillet and Ponge, 2003). Gut contents were characterized for each individual. Most intestines were void or displayed only one food category. In cases where several categories were present in the same gut, each category was scored to the nearest 0.1 , the sum of the scores being fixed to 1 for each individual. 
Densities of the different species, as well as total abundance of Collembola and

2 number of species per sample were compared between treatments using Mann-

3 Whitney procedure at .05 significance theshold (Glantz, 1997).

4

5 3. Results

6

The species composition of the dysmoder humus largely differed from that of

8 the polluted soil (Table 1, Fig. 1). The dysmoder humus exhibited more than ten times

9 the total abundance of the mor (polluted) humus, and more than three times its number of species. Some species were present in the acid soil but were totally lacking in the neutral (polluted) soil, the most abundant ones being Protaphorura eichhorni (Gisin),

12 Folsomia quadrioculata (Tullberg), Friesea truncata Cassagnau, Isotomiella minor 13 (Schäffer), Mesaphorura tenuisensillata Rusek and Ceratophysella denticulata 14 (Bagnall). They were classified as dysmoder species. Some others were present in the neutral soil, but were totally lacking in the acid soil, the most abundant ones being Protaphorura armata (Tullberg) and Lepidocyrtus cyaneus Tullberg. They were classified as mor species. Finally, some species were present in both substrates, such as M. macrochaeta, Parisotoma notabilis (Schäffer) and Sphaeridia pumilis

19 (Krausbauer). They were classified as common species.

No males were recorded in M. macrochaeta from the acid soil (337 ind.), while a quarter of the adults were males in the population from the neutral soil (189 ind.). Prominent differences were observed between dysmoder and mor in the distribution of gut contents (Fig. 2). Holorganic humus was dominant in $M$. macrochaeta from the beech forest, while empty guts, followed by hemorganic humus, were dominant in the polluted soil before incubation. Fungi were also notable in acid soil guts. On the

27 contrary fungi, together with bacteria and exuviae, were scarcely observed in the 28 neutral, polluted soil. 
After incubation, no decrease was observed in the number of individuals living

3 in the polluted soil (Table 1), but the number of species decreased to a large extent

4 (Table 1, Fig. 1). The collapse in species richness was due to the disappearance of

5 epigeic species such as Isotoma viridis Bourlet, L. cyaneus, Sminthurinus elegans

6 (Fitch), S. pumilis and Willowsia nigromaculata (Lubbock). However, two hemiedaphic

7 species were also observed to disappear at the end of the incubation period, namely $P$.

8 notabilis and Micranurida pygmaea Boerner. The dominant species M. macrochaeta

9 and $P$. armata, which comprised $80 \%$ of the total population, were not affected at all by

10 incubation conditions (Table 1).

11

12

13

14

Food habits of $M$. macrochaeta were not affected to a great extent by incubation, apart from a small increase in the proportion of empty guts (Fig. 2). After 6 months, hemorganic humus was still dominant in the food bolus, although mineral matter was practically absent in the holorganic humus used for the experiment, as ascertained by the composition of humus profiles (Gillet and Ponge, 2002). The sex ratio of $M$. macrochaeta changed little during the experiment, the proportion of males passing from a quarter to a third of the adult population (Table 1).

Inoculation with dysmoder fauna doubled the number of species of mor humus when compared with the incubated, uninoculated substrate (Table 1, Fig. 1), but it did not increase the number of individuals (Table 1). Thus, most introduced animals were not recovered at the end of the experiment. Only four dysmoder species were found after incubation, namely F. truncata, P. eichhorni, Pseudosinella alba (Packard) and Pseudosinella mauli Stomp, but only in very low densities (less than one specimen per microcosm in average). The abundance of $M$. macrochaeta, which was dominant in mor humus but was also present in dysmoder, was not affected by the inoculation procedure (Table 1), thus it can be concluded at first sight that most introduced 
1 specimens of $M$. macrochaeta died during incubation. On the contrary, the other

2 dominant species in the polluted soil, $P$. armata, decreased in abundance when acid-

3 tolerant fauna was inoculated, while it did not in the absence of inoculation (Table 1).

4

5

6

7

The examination of gut contents of $M$. macrochaeta at the end of the incubation period (Fig. 2) showed that inoculation of dysmoder fauna caused a small increase in empty guts, a strong decrease in the fraction of hemorganic humus and a strong increase in holorganic humus and fungi. The sex ratio of $M$. macrochaeta was not affected by inoculation (Table 1), suggesting that the population recovered at the end of the experiment was the original population of the mor humus.

\section{Discussion}

From our experimental results, it can be concluded that most inoculated specimens died within 6 months, despite an increase in species richness due to a trace population and thus that most acid-tolerant microarthropods were unable to colonize heavily polluted soil used for the experiment. Interestingly, introduced species like $M$. macrochaeta, which were abundant in the mor (polluted, neutral) humus, but were also abundant in the dysmoder (unpolluted, acidic) humus, died too. Only the original population of the polluted site can be considered tolerant to the environmental conditions (chemical, biotic) prevailing in mor humus. We ruled out the possibility of a mixing of $M$. macrochaeta specimens from the two sites in inoculated microcosms at the end of the experiment. Even though the examination of gut contents (more fungi, more holorganic humus, compared to uninoculated microcosms) could lead us to this conclusion, the absence of any change in the sex ratio clearly indicated that no parthenogenetic females from the dysmoder were added to the original population of the mor humus. The constant density of $M$. macrochaeta following inoculation indicated that no juveniles were added, too. The observed changes in gut contents could be 
1 caused by i) the fall of some debris which accompanied the escape by animals of the

2 drying substrate in Berlese funnels (although most of them were retrieved and sorted

3 out by hand after inoculation), ii) the use of cadavers of introduced specimens by the

4 original fauna of mor humus. The second cause is hardly probable, since arthropod

5 exoskeletons were absent from $M$. macrochaeta intestines in inoculated microcosms,

6 although some were observed in the absence of inoculation (Fig. 2).

7

The duration of the experiment was enough to allow reproduction to occur, 9 given the generation time (from egg to egg) of most Collembola (Siepel, 1994). In the presence of predators, the absence of any significant change in the collembolan population (apart from the disappearance of rare species, which is expected in microcosms) was indicative of an equilibrium condition. The disappearance of most introduced specimens could be due to saturation of the original population (Longstaff, 1976; Bernier and Ponge, 1998; Winkler and Kampichler, 2000) or to unfavourable food and environmental conditions. The first cause can be ruled out, given the abundance of food (decaying roots, fungi, humus) present in the sampled holorganic profiles, as ascertained from direct observation and from quantitative analyses (Gillet and Ponge, 2002). However, poor food quality could be suspected, since the food habits of introduced specimens of $M$. macrochaeta clearly differed from that of conspecific specimens living in the polluted soil. It is remarkable that mineral matter, which was nearly absent in the sampled profiles (Gillet and Ponge, 2002), was retrieved in high amount in the gut contents of $M$. macrochaeta, even after 6 months. This species was thus able to search for fine mineral particles (supposed to have detoxifying properties) in an environment in which these were nearly absent. It can be hypothesized that the population from the beech forest, where holorganic humus was the main food source but could be consumed without any danger, was unable to mix it with mineral matter in the polluted mor humus. The litter of the polluted mor was partly made of plant debris from hyper-accumulating plants such as Arabidopsis halleri (L.) 
1 O'Kane \& Al-Shehbaz, which accumulates zinc in its above-ground parts (Sarret et al.,

2 2002). The inadaptation of added specimens of $M$. macrochaeta to toxic food or soil

3 solution is a possible cause for the observed phenomenon. Ecotoxicological tests on

4 the isotomid springtail Folsomia candida have shown that reproduction and growth of

5 Collembola were affected by heavy metals, in particular $\mathrm{Cd}$ and $\mathrm{Zn}$, at doses far under

6 those found in our polluted soil (Sandifer and Hopkin, 1996; Smit et al., 1997; Crouau

7 et al., 1999), thus toxic effects were not unexpected. However, it has been

8 demonstrated that tolerance to heavy metals varies between populations of the same

9 species and that contamination by trace elements may select better-adapted 10 genotypes (Posthuma, 1990; Chenon et al., 2000). In the case of the two populations 11 we compared, that of Auby, living in a soil with 35,000 mg/kg Zn, $190 \mathrm{mg} / \mathrm{kg} \mathrm{Cd}$ and $126000 \mathrm{mg} / \mathrm{kg} \mathrm{Pb}$ (Gillet and Ponge, 2003) can be considered strongly adapted to heavy 13 metals, either by a better selection of its food (Fountain and Hopkin, 2001; Tranvik and 14 Eijsackers, 1989; present results) or by physiogical adaptation such as increased metal 15 excretion rate or shortening of the juvenile period (Posthuma et al., 1992, 1993) or by 16 shifting from parthenogenesis to sexual reproduction (Niklasson et al., 2000; Gillet and 17 Ponge, 2003; present results). At last, a shock effect caused by a sharp increase in pH 18 when animals living at $\mathrm{pH} 4$ were introduced into a soil of $\mathrm{pH} 7$ can be another possible 19 cause for the failure of colonization (Crouau et al., 1999), even for species know to live 20 over a wide range of $\mathrm{pH}$ conditions such as M. macrochaeta (Ponge, 1993).

\section{Acknowledgements}

23

24 We thank the Centre National de la Recherche Scientifique (Programme 25 Environnement, Vie et Sociétés) for financial support within a research project directed 26 by Pr. Daniel Petit (Lille). 
1

2

3 Bernier, N., 1998. Earthworm feeding activity and development of the humus profile.

4

5

6

7

8

9

10

12

13

14

15

16

19

20

21

22

23

24

25

26

27

\section{References} Biol. Fertil. Soils 26, 215-223.

Bernier, N., Ponge, J.F., 1998. Lumbricus terrestris L. distribution within an experimental humus mosaic in a mountain spruce forest. Biol. Fertil. Soils 28, 81-86.

Bretfeld, G., 1999. Synopses on palaearctic Collembola. II. Symphypleona. Abh. Ber. Naturkundemus. Görlitz 71, 1-318.

Brêthes, A., Brun, J.J., Jabiol, B., Ponge, J.F., Toutain, F., 1995. Classification of forest humus forms: a French proposal. Ann. Sci. For. 52, 535-546.

Chauvat, M., Ponge, J.F., 2002. Colonization of heavy metal-polluted soils by collembola: preliminary experiments in compartmented boxes. Appl. Soil Ecol. 21, 91-106.

Chenon, P., Rousset, A., Crouau, Y., 2000. Genetic polymorphism in nine clones of a parthenogenetic collembolan used in ecotoxicological testing. Appl. Soil Ecol. 14, 103-110.

Crouau, Y., Chenon, P., Gisclard, C., 1999. The use of Folsomia candida (Collembola, Isotomidae) for the bioassay of xenobiotic substances and soil pollutants. Appl. Soil Ecol. 12, 103-111. 
1 Davidson, D.A., Bruneau, P.M.C., Grieve, I.C., Young, I.M., 2002. Impacts of fauna in

4 an upland grassland soil as determined by micromorphological analysis. Appl. Soil Ecol. 20, 133-143.

Dupuy, N., Douay, F., 2001. Infrared and chemometrics study of the interaction between heavy metals and organic matter in soils. Spectrochimica Acta A 57, 1037-1047.

Edwards, C.A., Fletcher, K.E., 1971. A comparison of extraction methods for terrestrial arthropods. In: Phillipson, J. (Ed.), Methods of Study in Quantitative Soil Ecology: Population, Production and Energy Flow. Blackwell, Oxford, pp. 150185.

Fjellberg, A., 1998. The Collembola of Fennoscandia and Denmark. I. Poduromorpha. Brill, Leiden, p. 184.

Fountain, M.T., Hopkin, S.P., 2001. Continuous monitoring of Folsomia candida (Insecta: Collembola) in a metal exposure test. Ecotox. Environ. Safety B 48, 275-286.

Gillet, S., Ponge, J.F., 2002. Humus forms and metal pollution in soil. Eur. J. Soil Sci. 53, 529-539.

Gillet, S., Ponge, J.F., 2003. Changes in species assemblages and diets of Collembola along a gradient of metal pollution. Appl. Soil Ecol. 22, 127-138.

Gillet, S., Ponge, J.F., submitted. Are acid-tolerant collembolan communities able to colonise metal-polluted soil? 
2 Gisin, H., 1960. Collembolenfauna Europas. Museum d'Histoire Naturelle, Geneva, p. 3 312.

4

5 Glantz, S.A., 1997. Primer of Biostatistics, $4^{\text {rd }}$ ed. McGraw-Hill, New York, p. 473.

6

7 Hopkin, S.P. (in prep.). A key to the springtails of Britain and Ireland. AIDGAP Test 8 Version.

9

Jordana, R., Arbea, J.I., Simón, C., Luciáñez, M.J., 1997. Fauna Iberica. VIII. 11 Collembola Poduromorpha. Museo Nacional de Ciencias Naturales, and

13 Consejo Superior de Investigaciones Científicas, Madrid, p. 807.

Köhler, H.R., 2002. Localization of metals in cells of saprophagous soil arthropods (Isopoda, Diplopoda, Collembola). Microscopy Res. Tech. 56, 393-401.

16

17 Kreutzer, K., 1995. Effects of liming on soil processes. Plant Soil 168-169, 447-470.

18

19 Longstaff, B.C., 1976. The dynamics of collembolan populations: competitive relationships in an experimental system. Can. J. Zool. 54, 948-962.

21

22

Niklasson, M., Petersen, H., Parker, E.D.Jr, 2000. Environmental stress and 23 reproductive mode in Mesaphorura macrochaeta (Tullbergiinae, Collembola). Pedobiologia 44, 476-488.

25

Ponge, J.F., 1993. Biocenoses of Collembola in atlantic temperate grass-woodland ecosystems. Pedobiologia 37, 223-244. 
1 Ponge, J.F., 1999. Horizons and humus forms in beech forests of the Belgian Ardennes. Soil Sci. Soc. Am. J. 63, 1888-1901.

3

4 Ponge, J.F., Arpin, P., Sondag, F., Delecour, F., 1997. Soil fauna and site assessment in beech stands of the Belgian Ardennes. Can. J. For. Res. 27, 2053-2064.

6

7

Ponge, J.F, Charnet, F., Allouard, J.M., 2000. Comment distinguer dysmoder et mor? L'exemple de la forêt domaniale de Perche-Trappe (Orne). Rev. For. Fr. 52, 2337.

Posthuma, L., 1990. Genetic differentiation between populations of Orchesella cincta (Collembola) from heavy metal contaminated sites. J. Appl. Ecol. 27, 609-622.

Posthuma, L., Hogervorst, R.F., Van Straalen, N.M., 1992. Adaptation to soil pollution by cadmium excretion in natural populations of Orchesella cincta (L.) (Collembola). Arch. Environ. Contam. Toxicol. 22, 146-156.

Posthuma, L., Verweij, R.A., Widianarko, B., Zonneveld, C., 1993. Life-history patterns in metal-adapted Collembola. Oikos 67, 235-249.

20

Potapov, M., 2001. Synopses on Palaearctic Collembola. III. Isotomidae. Abh. Ber. Naturkundemus. Görlitz 73, 1-603.

23

24 Sandifer, R.D., Hopkin, S.P., 1996. Effects of pH on the toxicity of cadmium, 25 copper,lead and zinc to Folsomia candida Willem, 1902 (Collembola) in a standard laboratory test system. Chemosphere 33, 2475-2486. 
1 Sarret, G., Saumitou-Laprade, P., Bert, V., Proux, O., Hazemann, J.L., Traverse, A.,

4 Marcus, M.A., Manceau, A., 2002. Forms of zinc accumulated in the hyperaccumulator Arabidopsis halleri. Plant Physiol. 130, 1815-1826.

Senesi, N., Sposito, G., Martin, J.P., 1987. Copper (II) and iron (III) complexation by humic acid-like polymers (melanins) from soil fungi. Sci. Tot. Environ. 62, 241252.

Siepel, H., 1994. Life-history tactics in soil microarthropods. Biol. Fertil. Soils 18, 263278.

Smit, C.E., Van Beelen, P., Van Gestel, C.A.M., 1997. Development of zinc bioavailability and toxicity for the springtail Folsomia candida in an experimentally contaminated field plot. Environ. Poll. 98, 73-80.

Tan, K.H., 1982. Principles of Soil Chemistry. Dekker, New York, p. 267.

Tranvik, L., Eijsackers, H., 1989. On the advantage of Folsomia fimetarioides over Isotomiella minor (Collembola) in a metal polluted soil. Oecologia 80, 195-200.

Vandenbulcke, F., Grelle, C., Fabre, M.C., Descamps, M., 1998. Implication of the midgut of the centipede Lithobius forficatus in the heavy metal detoxification process. Ecotox. Environ. Safety 41, 258-268.

Winkler, H., Kampichler, C., 2000. Local and regional species richness in communities of surface-dwelling grassland Collembola: indication of species saturation. Ecography 23, 385-392. 
1 Zimdars, B., Dunger, W., 1994. Synopses on Palaearctic Collembola. I. Tullbergiinae.

2 Abh. Ber. Naturkundemus. Görlitz 68, 1-71. 
3 Fig. 1. Distribution of dysmoder, mor and common species in the four treatments.

4

5

6

7

8

9

10

11

12

13

14 DYSMODER = original acid (unpolluted) soil. MOR = original neutral (polluted) soil. $M O R+6=$ polluted soil after 6 -month incubation in microcosms. MOR+DYSMODER = polluted soil after inoculation with dysmoder arthropods and 6-month incubation in microscoms. Letters indicate significant differences between total numbers of species per sample $(n=10)$ according to the four treatments (Mann-Whitney $U$ test). Bars are means and whiskers are standard errors of the means.

Fig. 2. Distribution of gut contents of Mesaphorura macrochaeta according to the four treatments (codes of treatments according to Figure 1) 
Table 1 Population parameters of Collembola in the original substrates (dysmoder, mor) and after 6-month incubation in microcosms (means of 10 replicates followed by standard errors). Dysmoder species which were retrieved at the end of the experiment in mor humus are indicated in bold type. Letters in indices indicate significant differences between treatments (Mann-Whitney U test)

\begin{tabular}{|c|c|c|c|c|}
\hline & Dysmoder & Mor (original) & Mor (incubated) & $\begin{array}{l}\text { Mor (incubated, and } \\
\text { inoculated with fauna from } \\
\text { dysmoder) }\end{array}$ \\
\hline Allacma fusca & $0.1 \pm 0.1$ & 0 & 0 & 0 \\
\hline Arrhopalites spinosus & $0.5 \pm 0.2_{a}$ & $\mathrm{O}_{\mathrm{b}}$ & $\mathrm{O}_{\mathrm{b}}$ & $\mathrm{O}_{\mathrm{b}}$ \\
\hline Ceratophysella denticulata & $11 \pm 0.8 \mathrm{a}$ & $O_{b}$ & $O_{b}$ & $O_{b}$ \\
\hline Entomobrya nivalis & $0.6 \pm 0.5$ & 0 & 0 & 0 \\
\hline Folsomia quadrioculata & $67.4 \pm 6.8 \mathrm{a}$ & $O_{b}$ & $\mathrm{O}_{\mathrm{b}}$ & $\mathrm{O}_{\mathrm{b}}$ \\
\hline Friesea truncata & $51.1 \pm 4.4_{a}$ & $\mathbf{O}_{\mathrm{c}}$ & $0_{c}$ & $0.8 \pm 0.3_{b}$ \\
\hline Heteromurus major & $0.1 \pm 0.1$ & $0.1 \pm 0.1$ & $0.1 \pm 0.1$ & 0 \\
\hline Isotoma viridis & 0 & $0.1 \pm 0.1$ & 0 & 0 \\
\hline Isotomiella minor & $42.8 \pm 3.5 a$ & $\mathrm{O}_{\mathrm{b}}$ & $\mathrm{O}_{\mathrm{b}}$ & $\mathrm{O}_{\mathrm{b}}$ \\
\hline Lepidocyrtus cyaneus & $\mathrm{O}_{\mathrm{b}}$ & $1.3 \pm 0.5 \mathrm{a}$ & $\mathrm{O}_{\mathrm{b}}$ & $\mathrm{O}_{\mathrm{b}}$ \\
\hline Lepidocyrtus lignorum & $0.2 \pm 0.2$ & 0 & 0 & 0 \\
\hline Lipothrix lubbocki & $6.6 \pm 1_{a}$ & $O_{b}$ & $O_{b}$ & $\mathrm{O}_{\mathrm{b}}$ \\
\hline Megalothorax minimus & $5.4 \pm 0.8 \mathrm{a}$ & $\mathrm{O}_{\mathrm{b}}$ & $\mathrm{O}_{\mathrm{b}}$ & $\mathrm{O}_{\mathrm{b}}$ \\
\hline Mesaphorura leitzaensis & $0.1 \pm 0.1$ & 0 & 0 & 0 \\
\hline Mesaphorura macrochaeta & $33.7 \pm 3_{a}$ & $18.8 \pm 6.5_{b}$ & $20.1 \pm 7.1_{b}$ & $20.6 \pm 7.2_{b}$ \\
\hline (sex ratio $M / F)$ & 0 & 0.26 & 0.32 & 0.34 \\
\hline Mesaphorura jevanica & $7.7 \pm 1.2_{\mathrm{a}}$ & $0_{b}$ & $\mathrm{O}_{\mathrm{b}}$ & $\mathrm{O}_{\mathrm{b}}$ \\
\hline Mesaphorura tenuisensillata & $19.3 \pm 3.9 a$ & $O_{b}$ & $\mathrm{O}_{\mathrm{b}}$ & $\mathrm{O}_{\mathrm{b}}$ \\
\hline Mesaphorura yosii & $6.4 \pm 1.4_{a}$ & $\mathrm{O}_{\mathrm{b}}$ & $\mathrm{O}_{\mathrm{b}}$ & $\mathrm{O}_{\mathrm{b}}$ \\
\hline Micranurida pygmaea & $\mathrm{O}_{\mathrm{b}}$ & $0.4 \pm 0.2_{a}$ & $\mathrm{O}_{\mathrm{b}}$ & $\mathrm{O}_{\mathrm{b}}$ \\
\hline Paratullbergia callipygos & $0.3 \pm 0.2$ & 0 & 0 & 0 \\
\hline Parisotoma notabilis & $11.1 \pm 1.6_{\mathrm{a}}$ & $1.8 \pm 0.4_{b}$ & $0_{c}$ & $0_{c}$ \\
\hline Proisotoma minima & $0.4 \pm 0.4$ & 0 & 0 & 0 \\
\hline Protaphorura armata & $0_{c}$ & $7.5 \pm 1.1_{\mathrm{a}}$ & $8 \pm 4.3_{\mathrm{ab}}$ & $3.6 \pm 1.2_{b}$ \\
\hline Protaphorura eichhorni & $128.9 \pm 13.9_{a}$ & $\mathbf{O}_{\mathrm{b}}$ & $\mathrm{O}_{\mathrm{b}}$ & $0.5 \pm 0.3_{b}$ \\
\hline Pseudanurophorus binoculatus & $0.7 \pm 0.4$ & 0 & 0 & 0 \\
\hline Pseudisotoma sensibilis & $2.1 \pm 0.8_{a}$ & $\mathrm{O}_{\mathrm{b}}$ & $\mathrm{Ob}_{\mathrm{b}}$ & $\mathrm{O}_{\mathrm{b}}$ \\
\hline Pseudosinella alba & $0.4 \pm 0.2$ & 0 & 0 & $0.2 \pm 0.1$ \\
\hline Pseudosinella mauli & $2.2 \pm 0.4 a$ & $\mathbf{O}_{\mathrm{c}}$ & $\mathbf{O}_{\mathrm{c}}$ & $0.5 \pm 0.2_{b}$ \\
\hline Schaefferia emucronata & $0.3 \pm 0.2_{a}$ & $\mathrm{O}_{\mathrm{b}}$ & $\mathrm{O}_{\mathrm{b}}$ & $\mathrm{O}_{\mathrm{b}}$ \\
\hline Sminthurinus elegans & $\mathrm{O}_{\mathrm{b}}$ & $0.5 \pm 0.2_{a}$ & $\mathrm{O}_{\mathrm{b}}$ & $\mathrm{O}_{\mathrm{b}}$ \\
\hline Sminthurinus signatus & $0.2 \pm 0.1$ & 0 & 0 & 0 \\
\hline Sphaeridia pumilis & $0.2 \pm 0.2_{b}$ & $1.7 \pm 0.6 \mathrm{a}$ & $\mathrm{O}_{\mathrm{b}}$ & $0.3 \pm 0.3_{b}$ \\
\hline Willemia anophthalma & $4.9 \pm 1.2_{a}$ & $\mathrm{O}_{\mathrm{b}}$ & $\mathrm{O}_{\mathrm{b}}$ & $\mathrm{O}_{\mathrm{b}}$ \\
\hline Willemia denisi & $1.1 \pm 0.4_{a}$ & $\mathrm{O}_{\mathrm{b}}$ & $\mathrm{O}_{\mathrm{b}}$ & $\mathrm{O}_{\mathrm{b}}$ \\
\hline Willowsia nigromaculata & 0 & $0.1 \pm 0.1$ & 0 & 0 \\
\hline Total Collembola & $405.8 \pm 32.3_{a}$ & $32.3 \pm 7.6_{b}$ & $28.2 \pm 7.5_{b}$ & $26.5 \pm 7.3_{b}$ \\
\hline Number of species & $17.9 \pm 0.6_{a}$ & $5.1 \pm 0.6_{b}$ & $1.5 \pm 0.2_{d}$ & $3.3 \pm 0.5_{c}$ \\
\hline
\end{tabular}




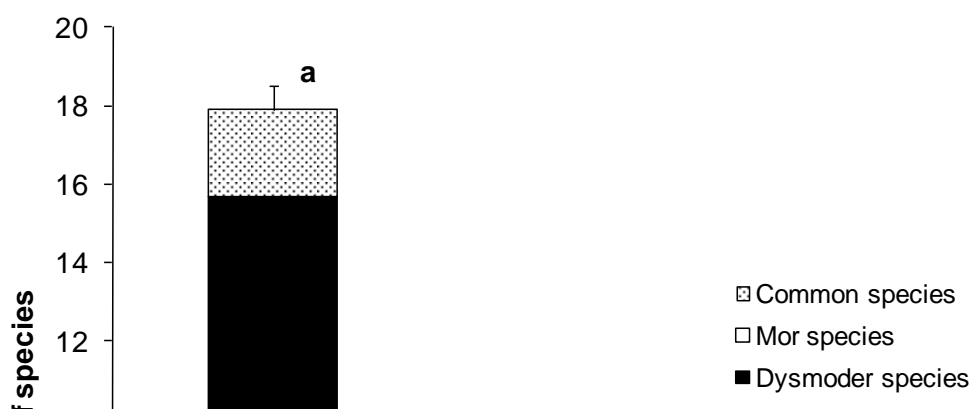

1

DYSMODER

Mor species

- Dysmoder species

2 Fig. 1

3 

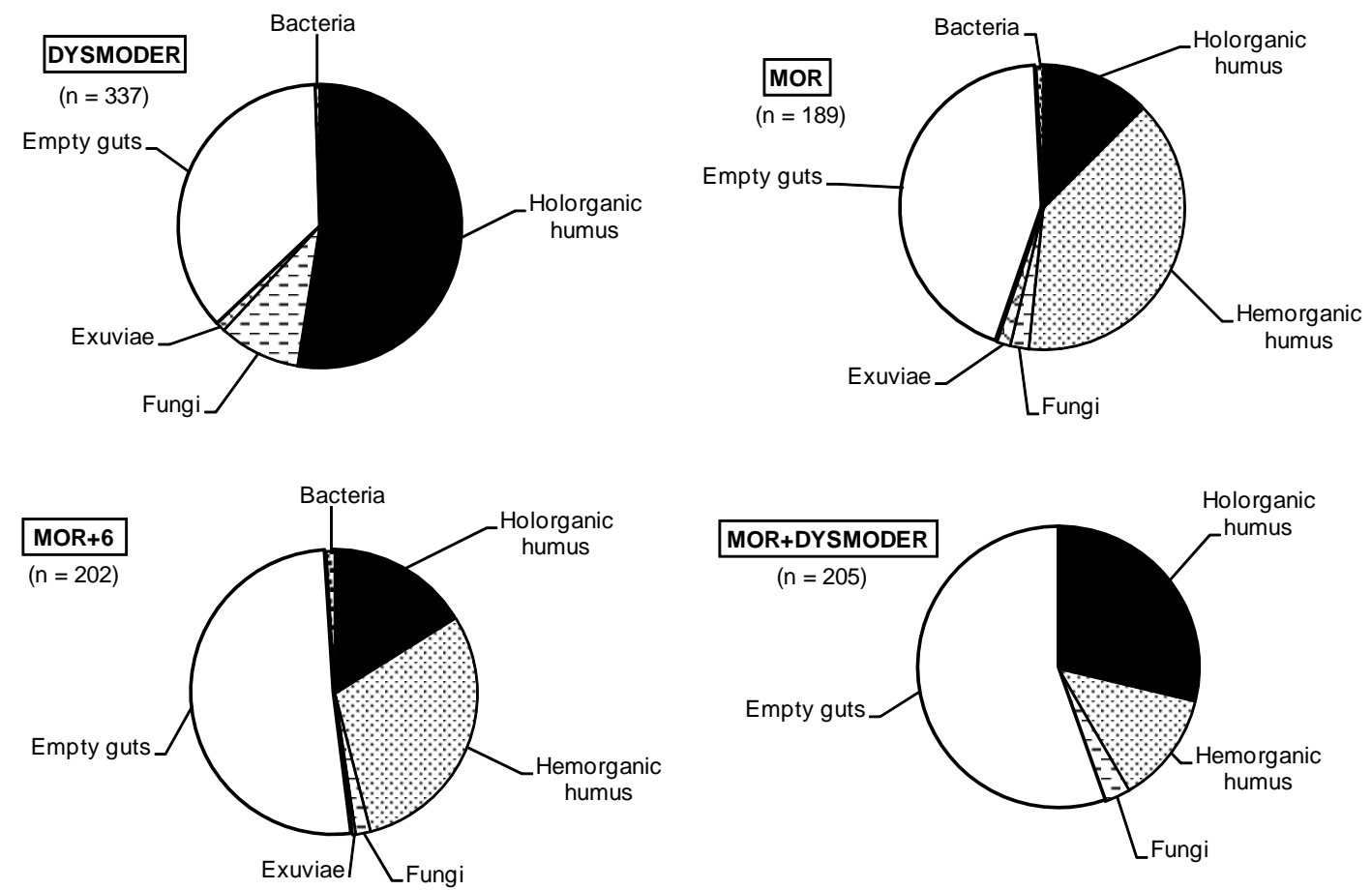

2

Fig. 2 